\title{
Metabolism of microbes, nematodes, polychaetes, and their interactions in sediment, as detected by heat flow measurements*
}

\author{
Mario M. Pamatmat and Stuart Findlay \\ Tiburon Center for Environmental Studies, San Francisco State University, Tiburon, California 94920, USA
}

\begin{abstract}
Heat flow of closed artificial systems, consisting of flooded clean sand with added food, shows the usual growth pattern of microbes in a batch culture: rapid growth with concomitant increase in metabolic heat production to a peak level, followed by exponential decline. Heat flow from the same system with nematodes (Diplolaimella chitwoodi) and polychaetes (Capitella capitata) indicates different rates and patterns of growth and metabolism of the microbial community in the presence of worms. The nematode prolonged the lag phase and prevented the microbial populations from reaching the peak metabolic rate without nematodes. C. capitata maintained system metabolism and microbial population at relatively steady state. The greater the food ration per $\mathrm{mg}$ of polychaete the greater the microbial heat production. Unfed $C$. capitata showed an exponentially decreasing metabolic rate to a level, by the end of $24 \mathrm{~h}$, about a sixth that of the worms with food. Direct calorimetry can just as easily measure the energy flow of natural soft-bottom ecosystems, and the effects of species added to it. On the other hand, results indicate the extreme difficulty of partitioning system energy flow into its metabolic compartments (by species, size, or functional groups) without uncoupling interaction effects.
\end{abstract}

\section{INTRODUCTION}

The relative importance of component species populations in a benthic community has been assessed in terms of their numbers and biomass, metabolic activity, growth or production, and energy flow. This type of comparison gives us a limited understanding of species interactions. It may indicate superiority of some species in competing for available food resources but it tells nothing about how one species directly affects another, or the community as a whole. In general, the presence of one species or another has been shown to increase sediment oxygen uptake, rate of detrital decomposition, and other measures of microbial activity, indicating indirect synergistic effects (Fenchel, 1970; Hargrave, 1970; Gerlach, 1978; Briggs et al., 1979; Findlay and Tenore, 1982).

We describe experiments to show how heat flow measurements can be used to determine (1) the growth

- Contribution No. 5, Tiburon Center for Environmental Studies, P. O. Box 855, Tiburon, California 94920, USA. of microorganisms and (2) the effects of added nematodes (Diplolaimella chitwoodi) and polychaetes (Capitella capitata) on the microbial growth in benthic ecosystems. Our data indicate that the metabolic activity of 2 or more component species measured together is not equal to their separate metabolism. The discrepancy is an indication of synergistic or antagonistic effects.

Microcalorimetry has been used for a long time in the study of microbial growth and metabolism (Forrest, 1972). Its application to ecological problems has lagged, partly because of technical difficulties and the relatively high cost of commercially available instruments, and also because of a general lack of appreciation of what heat flow measurements can contribute to ecological understanding that no other present technique can duplicate. Direct calorimetry measures energy flow directly (Pamatmat et al., 1981; Pamatmat, 1982), in contrast to other techniques that measures fluxes or turnover of matter, e.g. oxygen, carbon as carbon dioxide or carbon-14-labeled organic substrate, electrons, etc. The results to be presented will illustrate the value of direct calorimetry in modern ecology. 


\section{MATERIALS AND METHODS}

In each experiment $100 \mathrm{~cm}^{3}$ of clean white sand that had passed a $0.3 \mathrm{~mm}$ mesh was placed in a $100 \mathrm{~mm}$ diameter $\times 50 \mathrm{~mm}$ depth crystallizing dish (total volume, $350 \mathrm{~cm}^{3}$; surface area $74 \mathrm{~cm}^{2}$ ). The dish was halffilled with $1-\mu m$-filtered estuarine water $(25 \% \mathrm{~S})$ and kept at $20^{\circ} \mathrm{C}$. This set-up constitutes the experimental control. Pablum (Gerbers Mixed Cereal), a baby food of known chemical composition used in faunal feeding experiments (Tenore, 1981), was added to some of the dishes. Known numbers of polychaetes or nematodes were added to the dishes, both with and without Pablum, simulating natural densities of these organisms $\left(10^{6}\right.$ nematodes $\mathrm{m}^{-2} ; 2,700$ to 13,500 polychaetes $\left.\mathrm{m}^{-2}\right)$.

The mass cultures of the nematode had been maintained on Pablum in $75 \mathrm{~cm}^{2}$ tissue culture flasks and were in late log phase of growth. They were separated from the Pablum by a modified Baermann extraction technique (Sikora et al., 1977) and washed to obtain a clean suspension. The required volume of worm suspension to contain 7,000 nematodes $\left(=10^{6} \mathrm{~m}^{-2}\right)$ was added to the dish.

The stock culture of polychaetes had likewise been maintained on Pablum in culture trays with flowing filtered estuarine water at $20^{\circ} \mathrm{C}$. Just before the experiment, a requisite number of worms of nearly the same size were blotted dry and wet-weighed. All this treatment and handling had no noticeable untoward effect on these animals. When transferred to a dish they quickly dispersed, disappeared into the sand, and later could be seen next to the bottom and sides of the dish. After the experiment, the worms were picked out of the sediment and wet-weighed again.

For heat flow measurement each dish was placed inside a 0.5 -I tin can which had been corrosion-proofed with epoxy spray paint. A few $\mathrm{ml}$ of water were placed in the bottom of the can to facilitate heat conduction from the sediment and water inside the dish, through the glass and to the metal can in contact with the calorimeter's heat-flow sensors. The can was completely sealed with a double layer of oversize rubber bands.

The instrument was a double-twin heat-flow calorimeter (Pamatmat, in press) modified to contain 0.5-1 respiration chambers in the upright position. The calorimetry technique and calibration has been described in detail (Pamatmat, 1978). The instrument produces a thermopile voltage in direct proportion to the rate of heat flow through its semiconductor thermoelectric sensors. The continuous recording of voltage versus time is called a thermogram. At steady heat flow the rate of heat flow through the sensors is identical to the rate of heat production, which is then directly proportional to the displayed thermopile voltage.

\section{RESULTS}

\section{Effect of food addition}

When water was first added to dry sand there was a low level of heat production, which increased until the
Fig. 1. Thermograms of flooded sand. (A) Flooded sand with $12 \mathrm{mg}$ Pablum during first day; and flooded sand with $12 \mathrm{mg}$ Pablum on first day, kept in flowing filtered water, and given another $12 \mathrm{mg}$ Pablum the next day just before placing it inside the calorimeter. The area covered with hash marks, equivalent to $29.9 \mathrm{~J}$, estimates the chemical energy of Pablum that was metabolized into heat in $22.5 \mathrm{~h} \mathrm{l}=15 \%$ of the heat of combustion of $12 \mathrm{mg}$ Pablum). (B) Flooded sand with 7000 nematodes, flooded sand with old nematode culture fluid plus $12 \mathrm{mg}$ Pablum, and flooded sand with 7000 washed nematodes plus $12 \mathrm{mg}$ Pablum. The effect of nematodes is to prolong the lag phase of microbial growth and prevent them from attaining their maximum population size

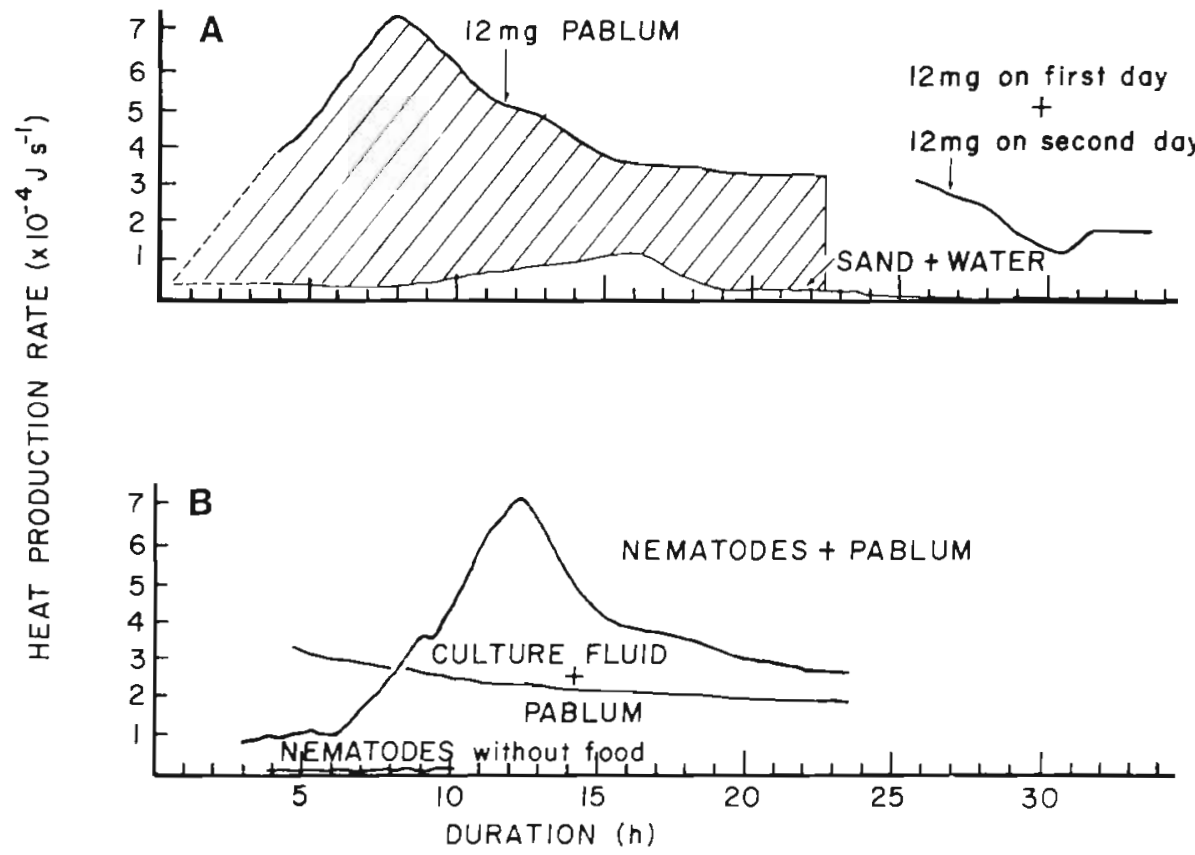


16 th $\mathrm{h}$ to $1.2 \times 10^{-4} \mathrm{~J} \mathrm{~s}^{-1}$ before decreasing to undetectable level (Fig. 1 A). The initial heat production may have been mostly physical-chemical but the ensuing 7 to $8 \mathrm{~h}$ period of increase was probably due to bacterial growth on available organic matter on the sand particles as well as dissolved organics in the estuarine water. As the bacterial substrate was used up the population declined, with a corresponding decrease in metabolic heat production rate.

The addition of $12 \mathrm{mg}$ of Pablum to flooded sand causes heat production rate to increase faster and reach a higher peak $\left(7.3 \times 10^{-4} \mathrm{~J} \mathrm{~s}^{-1}\right)$ sooner. The first $4 \mathrm{~h}$ of the thermogram was not usable because of the temporary disturbance in the instrument's thermal equilibrium. The dashed lines are a reasonable back extrapolation to indicate the course of heat energy conversion during the unobservable period. The difference between the first and second thermograms, the area shown by hash marks $(=29.9 \mathrm{~J})$ is an estimate of the total potential chemical bond energy of Pablum that was converted into heat during this period. In the 22.5-h period shown the microbial community oxidized nearly $15 \%$ of the chemical energy in $12 \mathrm{mg}$ of Pablum (heat of combustion of $4.0 \mathrm{cal} \mathrm{mg}^{-1}=16.7 \mathrm{~J} \mathrm{mg}^{-1}$; Tenore, 1981).

In the third part of this experiment, $12 \mathrm{mg}$ Pablum was added to the flooded sand. The dish was kept for $24 \mathrm{~h}$ in an open aquarium with flowing filtered water at $20^{\circ} \mathrm{C}$. On the second day another $12 \mathrm{mg}$ of Pablum was added to the dish before placing it inside the calorimeter. This sample did not show a second peak in heat production similar to that resulting from an initial addition of Pablum (Fig. 1 A). Instead it showed what appears to be the second day continuation of the previous experiment's thermogram, and the second batch of $12 \mathrm{mg}$ Pablum resulted in only a relatively minor increase to, and leveling at, $1.9 \times 10^{-4} \mathrm{~J} \mathrm{~s}^{-1}$.

\section{Effects of nematodes}

Sand with 7000 nematodes without food shows barely detectable heat production (Fig. 1 B). The nematode culture fluid plus $12 \mathrm{mg}$ of Pablum shows slowly decreasing heat production rate from $3 \times 10^{-4} \mathrm{~J} \mathrm{~s}^{-1}$ leveling off to $2 \times 10^{-4} \mathrm{~J} \mathrm{~s}^{-1}$ by the 24 th $\mathrm{h}$. The presence of 7000 nematodes with $12 \mathrm{mg}$ Pablum shows an increase to $7.1 \times 10^{-4} \mathrm{~J} \mathrm{~s}^{-1}$ by the 12 th $h$, decreasing thereafter. The peak here occurred about 4 h later than that of sand + Pablum only (Fig. $1 \mathrm{~A})$. Besides the difference in time lag, the thermogram of the sample with nematodes is lower than that of the sample without nematodes; the area under the curve is smaller but the time course of heat production is about the same, with some instantaneous differences.

From the differences in total heat production curves nematodes appear to affect the rate of bacterial population growth in 2 ways: they prolong the lag phase in bacterial population growth and they reduce the total energy flow as well. The diminished heat production signifies a smaller bacterial population. However, there appears to be something in the old nematode culture fluid, some metabolites perhaps, that are inimical to microbes. The nematodes had been washed but there may have been some substances carried over from the culture to the sand to affect bacterial growth. Thus, the possibility exists that the lag and depression described before were not purely the effects of nematodes. If they were, they could be the combined result of competition for food and predation on bacteria.

\section{Effects of Capitella capitata}

In the first experiment (Fig. 2) 20 polychaetes $\left(=2,700 \mathrm{~m}^{-2}\right)$ and $29 \mathrm{mg}$ of Pablum $\left(=3.9 \mathrm{~g} \mathrm{~m}^{-2} \mathrm{~d}^{-1}\right)$
Fig. 2. Thermograms on second day of Capitella capitata and microbes in sand, with $29 \mathrm{mg}$ of Pablum $\mathrm{d}^{-1}$. The second day's ration was added just before placing the dish inside the calorimeter. Final wet weights of worms are shown
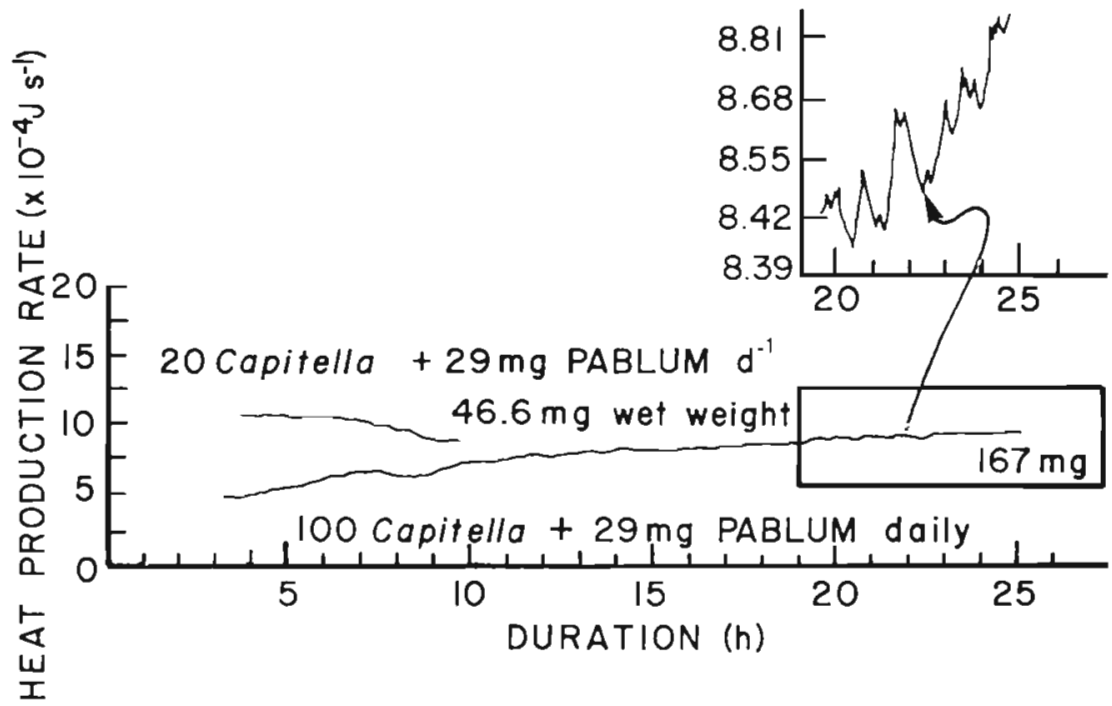
were added to a dish, which was kept submerged in a tray with flowing filtered estuarine water for ca. $24 \mathrm{~h}$. The following day $29 \mathrm{mg}$ of Pablum was again added to the dish before transferring the dish inside the calorimeter. The thermogram on the second day shows an average heat production rate of $10.3 \times 10^{-4} \mathrm{~J} \mathrm{~s}^{-1}$ decreasing to $9.2 \times 10^{-4} \mathrm{~J} \mathrm{~s}^{-1}$. When 100 Capitella capitata $+29 \mathrm{mg}$ Pablum $\mathrm{d}^{-1}$ were added to a separate dish (Fig. 2), the heat production rate was lower $\left(5 \times 10^{-4} \mathrm{~J} \mathrm{~s}^{-1}\right)$ and increased slowly during the second day. It is interesting that total heat production rate (= system energy flow) with $29 \mathrm{mg}$ Pablum but different amounts of worms was obviously very different in the two cases during the first day but converged during the second day to about $9 \times 10^{-4} \mathrm{~J} \mathrm{~s}^{-1}$. Obviously, the same processes (Capitella growth and metabolism, microbial growth and metabolism) occurred at different rates in the beginning and followed different time courses to reach the same final combined energy flow by the end of the second day. The group of 20 C. capitata gained weight while the batch of 100 lost weight. Thus the decrease in system energy flow with 20 worms indicates a slowly decaying microbial population. On the other hand, the increase in system energy flow with 100 evidently starving $C$. capitata implies that the worms initially kept microbial populations down but slowly the microbes increased in numbers.

By suppressing $39 \mu \mathrm{v}$ and increasing the sensitivity of the recording, the trend (Fig, 2) can be clearly seen to increase from $8.42 \times 10^{-4}$ to $8.81 \times 10^{-4} \mathrm{~J} \mathrm{~s}^{-1}$ in $5 \mathrm{~h}$. Furthermore, short-term fluctuations can be seen. Such fluctuations are not noise and appear to be caused by variations in the polychaete's metabolic activity, presumably a consequence of their incessant crawling movement. A similar dish containing only sand and
Pablum, without Capitella capitata, does not show these fluctuations.

In the second set of experiments (Fig. 3 A), 20 Capitella capitata $+12 \mathrm{mg}$ of Pablum were added to a dish daily. One dish was prepared each day for 3 successive days, giving 3 replicate runs. Each dish was kept in flowing water the first day and given $12 \mathrm{mg}$ of Pablum the next day just before placing it inside the calorimeter. The rate of heat production is about $40 \%$ of the dish that contained the same number of polychaetes fed $29 \mathrm{mg}$ of Pablum daily. Average heat production rates were $3.5 \times 10^{-4}, 3.8 \times 10^{-4}$, and $4.2 \times 10^{-4} \mathrm{~J} \mathrm{~s}^{-1}$ for the 3 dishes containing $37.0,44.1$, and $49.2 \mathrm{mg}$ of $C$. capitata, respectively. These heat production rates, while showing fluctuations due to polychaete activity, are steady on the average in comparison with that of microbes alone (Fig. $1 \mathrm{~A}$, second day). The metabolic rate of microbes alone with $12 \mathrm{mg}$. Pablum on the second day is about half of the polychaetes and microbes with $12 \mathrm{mg}$ Pablum on the second day.

\section{Metabolic rate of feeding versus non-feeding Capitella}

In the last experiment 100 Capitella capitata were added to the dish without Pablum (Fig. 3 B). Heat production rate was about $2.1 \times 10^{-4} \mathrm{~J} \mathrm{~s}^{-1}$ initially, decreasing exponentially to $1.2 \times 10^{-4} \mathrm{~J} \mathrm{~s}^{-1}$ over a period of $20 \mathrm{~h}$. The worms weighed $125 \mathrm{mg}$, so their average metabolic rate decreased from $1.7 \times 10^{-6}$ to $9.6 \times 10^{-7} \mathrm{~J} \mathrm{~s}^{-1} \mathrm{mg}^{-1}$. We assume that microbial metabolism was negligible at all times in Fig. $3 \mathrm{~B}$ and the decrease in total heat production rate was due to starvation of the worms.

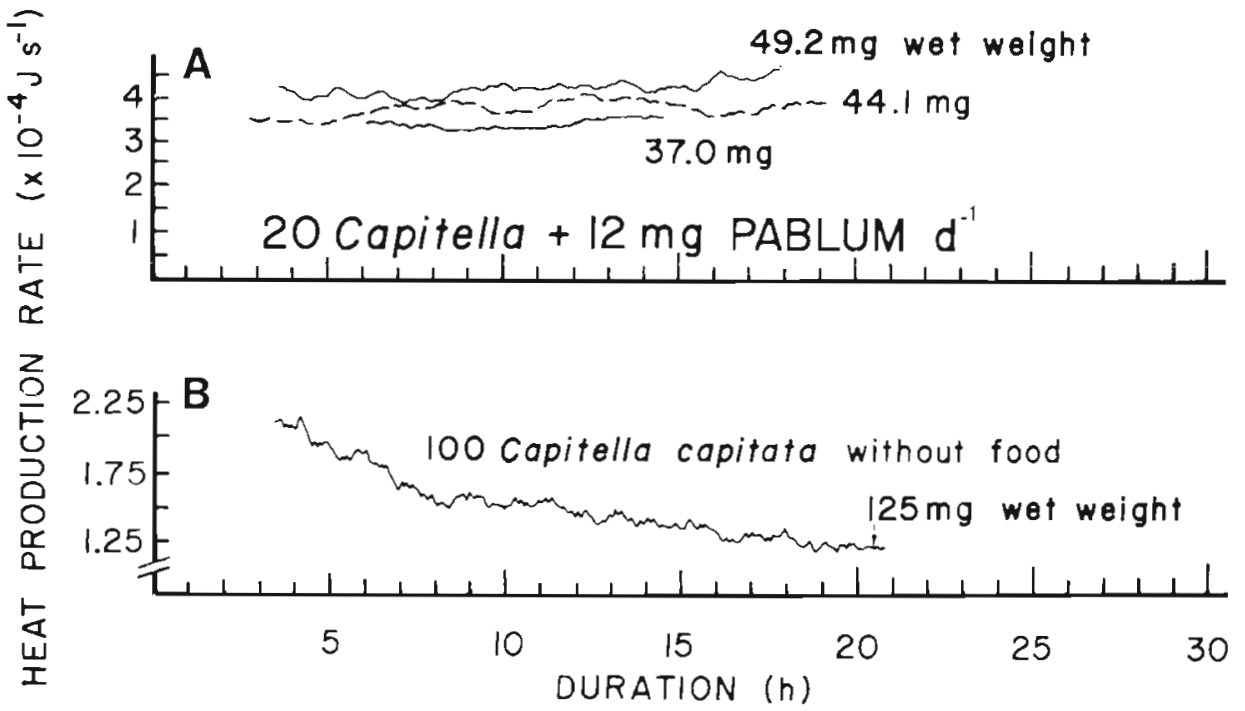

Fig. 3. Thermograms. (A) On second day of Capitella capitata and microbes in sand, with $12 \mathrm{mg}$ of Pablum $\mathrm{d}^{-1}$. The second day's ration was added just before placing the dish inside the calorimeter. Final worm biomass for each of 3 replicates is shown. (B) 100 Capitella capitata in sand without added food 
The relatively steady average rates in Fig. $3 \mathrm{~A}$ as compared to Fig. $3 \mathrm{~B}$ signify relatively steady metabolic activity in feeding worms. Unfortunately, we cannot derive microbial metabolism from Fig. $1 \mathrm{~A}$ and subtract it from total metabolism in Fig. 2 or $3 \mathrm{~A}$ to estimate the metabolic activity of feeding worms. Instead, if we assume that the difference in heat production rate between any 2 dishes in Fig. 3 A (with 20 Capitella capitata $+12 \mathrm{mg}$ Pablum) is due mainly to the difference in worm biomass, then the difference of $0.3 \times 10^{-4} \mathrm{~J} \mathrm{~s}^{-1}$ can be divided by the corresponding difference in worm biomass of $7.1 \mathrm{mg}$, giving $4.2 \times 10^{-6} \mathrm{~J} \mathrm{~s}^{-1} \mathrm{mg}^{-1}$. Likewise, the corresponding differences between 2 other dishes give $7.8 \times 10^{-6}$ and $5.7 \times 10^{-6} \mathrm{~J} \mathrm{~s}^{-1} \mathrm{mg}^{-1}$. These 3 values give an average of $5.9 \times 10^{-6} \mathrm{~J} \mathrm{~s}^{-1} \mathrm{mg}^{-1}$ for feeding worms versus $9.6 \times 10^{-7} \mathrm{~J} \mathrm{~s}^{-1} \mathrm{mg}^{-1}$ for starving ones by the end of $20 \mathrm{~h}$ inside the calorimeter. Theoretically, the exponential curve in Fig. $3 \mathrm{~B}$ could be back extrapolated, not to time zero when the system was placed inside the calorimeter, but several hours earlier when the worms were sieved out of the sediment. In spite of some uncertainty in back extrapolating that particular curve, doing so brings the metabolic rate of $C$. capitata without food in close agreement with that of feeding $C$. capitata.

Independent measurements of Capitella capitata respiration (Leon Camen and Kenneth Tenore, unpubl.) in terms of oxygen uptake, carbon dioxide production, and weight loss show equivalent heat production rates from $1.4 \times 10^{-6}$ to $12.6 \times 10^{-6} \mathrm{~J} \mathrm{~s}^{-1} \mathrm{mg}^{-1}$ (assuming $\mathrm{RQ}=1,1 \mathrm{ml} \mathrm{O}=20.1 \mathrm{~J}, 8.4 \%$ of wet weight $=\mathrm{g}$ carbon). The lower rates could have been due to starvation. Obviously, the shorter the delay in starting the experiment after picking the animals and the shorter the duration of the experiments the smaller will be the effect of starvation on metabolic activity. The rates in the high range mean that there are other factors that affect the measurements of respiration of this species and/or the conversion of respiration to heat.

\section{Partitioning total heat production between microbes and Capitella}

In the absence of polychaetes, microbial metabolism on the second day, with $12 \mathrm{mg}$ Pablum $\mathrm{d}^{-1}$, leveled off at $1.9 \times 10^{-4} \mathrm{~J} \mathrm{~s}^{-1}$ (Table 1 ).

Applying the average value of $5.9 \times 10^{-6} \mathrm{~J} \mathrm{~s}^{-1} \mathrm{mg}^{-1}$ of feeding worms to the worms in Fig. 2, the 20 Capitella capitata (46.6 $\mathrm{mg}$ ) accounted for a rate of $2.8 \times 10^{-4} \mathrm{~J} \mathrm{~s}^{-1}$; thus, $10.3 \times 10^{-4} \mathrm{~J} \mathrm{~s}^{-1}$ minus $2.8 \times 10^{-4} \mathrm{~J} \mathrm{~s}^{-1}$, or $7.5 \times 10^{-4} \mathrm{~J} \mathrm{~s}^{-1}$, should represent average microbial metabolism alone during that time (Table 1). These worms showed an average weight increase of $23 \%$ during the 2 -d experiment. The same calculations with the 100 C. capitata in Fig. 2 gives a value of $9.8 \times 10^{-4} \mathrm{~J} \mathrm{~s}^{-1}$ for the worms. This rate is higher than the terminal rate of $8.8 \times 10^{-4} \mathrm{~J} \mathrm{~s}^{-1}$ for worms plus microbes. At 100 worms dish ${ }^{-1}$ with a ration of $0.17 \mathrm{mg}$ Pablum $\mathrm{mg}^{-1}$ C. capitata, the polychaetes lost weight; hence, their average metabolic rate was probably lower than $5.9 \times 10^{-6} \mathrm{~J} \mathrm{~s}^{-1} \mathrm{mg}^{-1}$ but higher than $9.6 \times 10^{-7} \mathrm{~J} \mathrm{~s}^{-1} \mathrm{mg}^{-1}$, that of worms without any food.

Multiplying the value of $5.9 \times 10^{-6} \mathrm{~J} \mathrm{~s}^{-1} \mathrm{mg}^{-1}$ of feeding worms by the biomass of worms in Fig. $3 \mathrm{~A}$ $(37.0,44.1$, and $49.2 \mathrm{mg})$ their total heat production rate is estimated at $2.2 \times 10^{-4}, 2.6 \times 10^{-4}$, and $2.9 \times 10^{-4} \mathrm{~J} \mathrm{~s}^{-1}$, respectively. Subtracting these values from the corresponding measured rates for microbes plus worms, we obtain $1.3 \times 10^{-4}, 1.2 \times 10^{-4}$, and $1.3 \times 10^{-4} \mathrm{~J} \mathrm{~s}^{-1}$ for average microbial metabolic rate in each of the 3 dishes. The ration of these worms seemed just enough to maintain their weight.

Overall, microbial metabolism was highest at the

Table 1. Summary of results and calculations of microbial and polychaete metabolism under different feeding rations and worm density

\begin{tabular}{|c|c|c|c|c|c|c|c|}
\hline \multirow{2}{*}{$\begin{array}{c}\text { Experi- } \\
\text { ment } \\
\text { number }\end{array}$} & \multicolumn{2}{|c|}{ Capitella capitata } & \multicolumn{2}{|c|}{ Pablum Ration } & \multicolumn{3}{|c|}{ Heat Production Rate $\left(\mathrm{J} \cdot \mathrm{s}^{-1}\right)$} \\
\hline & $\begin{array}{l}\text { No. per } \\
\text { dish }\end{array}$ & $\begin{array}{c}\text { Wet wt. } \\
\text { (mg) }\end{array}$ & $\mathrm{mg} \mathrm{d}^{-1}$ & $\underset{\text { worm }}{\mathrm{mg} \mathrm{mg}^{-1}}$ & Total * & Worms $*$ & Microbes $\cdots$ \\
\hline 1 & 0 & 0 & 12 & & $1.9 \times 10^{-4}$ & 0 & $1.9 \times 10^{-4}$ \\
\hline 2 & 20 & 46.6 & 29 & 0.62 & 10.3 & $2.8 \times 10^{-4}$ & 7.5 \\
\hline 3 & 100 & 167.0 & 29 & 0.17 & 8.8 & 9.8 & undetectable (?) \\
\hline 4 & 20 & 37.0 & 12 & 0.32 & 3.5 & 2.2 & 1.3 \\
\hline 5 & 20 & 44.1 & 12 & 0.27 & 3.8 & 2.6 & 1.2 \\
\hline 6 & 20 & 49.2 & 12 & 0.24 & 4.2 & 2.9 & 1.3 \\
\hline 7 & 100 & 125.0 & 0 & 0 & 1.2 & 1.2 & presumed zero (?) \\
\hline $\begin{array}{r}\quad \text { Total } \\
\cdots \text { Total } \\
\cdots \text { Total }\end{array}$ & $\begin{array}{l}\text { roduction } \\
\text { roduction } \\
\text { roduction }\end{array}$ & $\begin{array}{l}\text { by micr } \\
\text { by } C a p i \\
\text { by micre }\end{array}$ & $\begin{array}{l}\text { worms in } \\
\text { itata in e } \\
\text { ach dish }\end{array}$ & $\begin{array}{l}\text { h dish } \\
\text { dish }(=5.9 \\
\text { tal minus }\end{array}$ & ${ }^{-1} \mathrm{mg}^{-1} \mathrm{mul}$ & plied by wet & eight) \\
\hline
\end{tabular}


highest ration level, and lowest but slowly increasing at the lowest ration level.

Summary of results:

(1) Microbial growth is stimulated by Pablum on the first day, but the same amount of Pablum on the second day does not have the same effect.

(2) Nematodes prolong the lag phase of microbial growth on the first day and also prevent the microbes from reaching their peak population size.

(3) Old nematode culture fluid alone inhibits microbial growth.

(4) Capitella capitata maintain microbial metabolic rate at a steady level below that of microbes alone, given the same amount of food.

(5) The greater the number and biomass of $C$. capitata the more pronounced the effect on total metabolism by depressing microbial growth and metabolism.

(6) The larger the amount of food given to the same number and biomass of worms the higher the total system energy flow and the greater the fraction of it is due to microbial metabolism.

(7) Starving C. capitata show an exponential decline in metabolic rate.

(8) The metabolic rate of feeding $C$. capitata is higher than that of non-feeding $C$. capitata, the actual difference depending on the length of the starvation period.

\section{DISCUSSION}

Ther thermogram of sand plus Pablum shows a trend of metabolic rate characteristic of a batch culture of microorganisms. Unknown microbes in our experiments went through the logarithmic growth, stationary, and exponential decay phases (Forrest et al., 1961; Pamatmat et al., 1981).

Thermograms are descriptive of thermodynamic processes taking place in the system. As conditions within the system change, the thermodynamics, and, therefore, the thermogram patterns will change. The closed, oxic, artificial microecosystem described here has important differences from natural systems. Natural benthic systems are open systems, largely anaerobic, oxic only in a relatively thin surface layer, and subject to turbulent mixing, with consequent effects on oxygen supply. Under these natural conditions, the experiments performed here will produce different thermograms. Whether the first order trends in the results described will be the same remains to be seen. Much developmental work is needed to simulate more closely natural systems inside a calorimeter. Until we can do so experimental results must, of course, be viewed strictly in the context of the prevailing conditions of the system.
The free-living nematode Diplolaimella chitwoodi, at the same density that we have used in our experiment, tripled the rate of mineralization (measured in terms of $\mathrm{CO}_{2}$ production) of Gracilaria detritus (Findlay and Tenore, 1982). The increased $\mathrm{CO}_{2}$ production is much greater than nematode respiration alone, indicating a synergistic effect by the nematodes on the microbes. Likewise, nematodes increased oxygen consumption and decomposition of sludge (Abrams and Mitchell, 1980) and increased carbon utilization and nitrogen and phosphorus mineralization in soils (Anderson et al., 1981). These results suggest that nematodes play a regulatory role in mineralization and carbon flow, including overall system metabolism as could be measured by direct calorimetry. Our own data with nematodes, however, indicate that they suppress microbial metabolism, at least during the first $24 \mathrm{~h}$. The other studies were for much longer durations. Recent experiments have shown that bacterial production (as measured in terms of ${ }^{3} \mathrm{H}$-thymidine incorporation into DNA, Findlay et al., submitted) was unaffected by $D$. chitwoodi but bacterial numbers were reduced by $50 \%$ in the presence of this nematode. The lag and depression of heat production that we observed are consistent with a reduction in bacterial numbers.

The known effects of polychaetes on community metabolism are variable. Nereis succinea, a large, active, errant polychaete, caused a doubling of the rate of detritus oxidation due to bioturbation (Briggs et al., 1979). Abarenicola pacifica, a more sedentary and permanent burrow dweller, also enhanced detrital decomposition, possibly through a 'gardening' effect on microorganisms (Hylleberg, 1975). The enchytraeid Cognettia sphagnetorum increased microbial activity and organic matter decomposition (Standen, 1978). On the other hand, Capitella capitata, a tiny worm that does not markedly disturb the sediment as it moves about, did not increase the rate of detritus oxidation (Tenore, 1977), in contrast to Nephtys incisa, a much larger species (Tenore et al., 1977). Our findings with C. capitata show that it affects microbial metabolism, and, therefore, the rate at which the microbial community oxidizes organic matter. The quantitative effect is variable, depending at least on the number of worms and the amount of available food. The greater the amount of added food for about the same amount of worms the higher the microbial metabolic heat production rate (by a correspondingly higher population size). If food is limited microbial metabolism (and population size) is actually depressed by the worms but the combined metabolic heat production by worms and microbes, being relatively steady, is initially higher, then lower and finally higher than that of the microbes alone. 
In general, the effect of metazoans on microbial population growth and metabolism will depend, among other things, on (1) the amount of organic matter in the sediment and its rate of supply, (2) whether metazoans and microbes both utilize the organic matter directly, (3) whether metazoans are feeding on the microbes, and (4) whether transformation of the organic matter by one organism affects its utilizability by another. By these conditions alone interactive effects in a benthic system can be expected to vary with species composition as well as temporally. Further complications can be expected from various forms of physical and chemical alterations of the system, whether they are biologically mediated or not.

Our data show the potential value of heat flow measurements in unraveling the dynamic interactions among component species in natural soft-bottom communities. Natural communities are without question much more complex than the artificial experimental system that we started with but quantifiable changes in heat flow should just as readily be detected in natural benthic systems as we have seen. If a species has a significant impact on benthic energy flow, its addition to, or removal from, that system will be reflected by a change in total heat production. Other techniques may be more desirable than calorimetry for studying specific functions, the more of which we know the better we will understand benthic system dynamics. Realistically, however, because of their sheer complexity, we may not be able to integrate all those processes and their interactions into a single total effect. Direct calorimetry at present affords us a means of detecting the response of the entire system to various perturbations. In our present state of knowledge it will be well to view our knowledge of specific functions and their combined effects in the benthic system, i.e. simulation models, against a background of directly measured holistic effect such as system energy flow.

On the other hand, because of the generality of heat effects, by these measurements alone, we cannot be certain about the exact mechanism involved. From the nature of the thermograms, however, taking into consideration their periodicity, frequency, amplitude of fluctuations, rates of change, etc. we can formulate probable hypotheses about the processes involved much better than we can without the thermograms. With subsequent conjunctive chemical analyses and other flux and turnover measurements we should be able to reduce an initially general heat effect to a specific cause-and-effect relation. Needless to say, the accuracy of our deductions from thermogram data alone will be indicative of our understanding of benthic system dynamics. The level of present understanding is low and direct calorimetry has a significant role to play in accelerating progress by minimizing the number of false leads in this complex field of research.

Acknowledgements. This research was supported by National Science Foundation Grant No. OCE80-03197 to M M. Pamatmat and NSF Grant No. OCE78-25862 to K. L. Tenore. We express our thanks to Dr. Tenore for the use of his laboratory facilities at Skidaway Institute of Oceanography and for his comments on the manuscript, to J. McClain, L. Bryant and E. J. Chesney for their technical assistance.

\section{LITERATURE CITED}

Abrams, B. I., Mitchell, M. J. (1980). Role of nematode-bacterial interactions in heterotrophic systems with emphasis on sewage sludge decomposition. Oikos 35: 404-410

Anderson, R., Coleman, D., Cole, C., Elliott, E. (1981). Effects of the nematodes Aerobeloides sp. and Mesodiplogaster lheritieri on substrate utilization and nitrogen and phosphorus mineralization in soil. Ecology 62: 549-555

Briggs, K., Tenore, K. R., Hanson, R. (1979). The role of microfauna in detrital utilization by the polychaete, Nereis succinea (Frey and Leuckhart). J. exp. mar. Biol, Ecol. 36: 225-234

Fenchel, T. (1970). Studies on the decomposition of organic detritus derived from the turtle grass Thalassia testudinum. Limnol. Oceanogr 15: 14-20

Findlay, S., Meyer, J., Edward, R. (submitted). Measuring bacterial production via rate of incorporation of ${ }^{3} \mathrm{H}$-thymidine into DNA. Appl. Environ. Microbiol.

Findlay, S., Tenore, K. R. (1982). Effect of free-living marine nematode (Diplolaimella chitwoodi) on detrital carbon mineralization. Mar. Ecol. Prog. Ser. 8: 161-166

Forrest, W. W. (1972). Microcalorimetry. In: Norris, J. R., Ribbons, D. W. (eds.) Methods in microbiology, Vol. 6 B. Academic Press, London, p. 285-318

Forrest, W. W., Walker, D. J., Hopgood, M. F., (1961) Enthalpy changes associated with the lactic fermentation of glucose. J. Bact. 82: 685-690

Gerlach, S. (1978). Food-chain relationships in subtidal silty sand marine sediments and the role of meiofauna in stimulating bacterial productivity. Oecologia 33: 55-69

Hargrave, B. T. (1970). The effect of a deposit-feeding amphipod on the metabolism of benthic microflora. Limnol. Oceanogr 15: 21-30

Hylleberg, J. (1975). Selective feeding by Abarenicola pacifica with notes on Abarenicola vagabunda and a concept of gardening in lugworms. Ophelia 14: 113-117

Pamatmat, M. M. (1978). Oxygen uptake and heat production in a metabolic conformer (Littorina irrorata) and a metabolic regulator (Uca pugnax). Mar. Biol. 48: 317-325

Pamatmat, M. M. (1982). Heat production by sediment: ecological significance. Science, N. Y. 215: 395-397

Pamatmat, M. M. (in press). Simultaneous direct and indirect calorimetry. In: Gnaiger, E., Forstner, H. (eds.) Handbook on polarographic oxygen sensors: aquatic and physiological applications. Springer-Verlag, Berlin

Pamatmat, M. M., Graf, G., Bengtsson, W., Novak, C. S. (1981). Heat production, ATP concentration and electron transport activity of marine sediments. Mar. Ecol. Prog. Ser 4: 135-143

Sikora, J. P., Sikora, W. B., Erkenbrecher, C. W., Coull, B. C. (1977). The significance of carbon, ATP and calories of meiobenthic nematodes in partitioning benthic biomass. Ecology 44: 7-14 
Standen, V. (1978). The influence of soil fauna on decomposition by microorganisms in blanket bog litter J. Anim. Ecol. 47: 25-38

Tenore, K. R. (1977). Utilization of aged detritus derived from different sources by the polychaete, Capitella capitata. Mar Biol. 44: 51-55
Tenore, K. R. (1981). Organic nitrogen and caloric content of detritus. I. Utilization by the deposit-feeding polychaete, Capitella capitata. Estuar coast. Shelf Sci. 12: 39-47

Tenore, K. R., Tietjen, J., Lee, J. (1977). Effect of meiofauna on incorporation of aged eelgrass detritus by the polychaete, Nephtys incisa. J. Fish. Res. Bd Can. 34: 563-567

This paper was presented by Professor S. A. Gerlach; it was accepted for printing on October 15, 1982 